The Polish Journal of the Arts and Culture. New Series 5

(1/2017): 89-112 [ARTICLE]

DOI: $10.4467 / 24506249$ PJ.17.005.6812

\title{
Elyonim veTachtonim. Some Methodological Considerations on the Electronic Database of Angels, Demons and Ghosts in Early Rabbinic Literature
}

Wojciech Kosion

\begin{abstract}
This paper presents the background, ambitions and the initial achievements of the Elyonim veTachtonim research project aimed at constructing an electronic database of accounts involving angels, demons and ghosts in early rabbinic literature. The first part summarises the history and transformations of the project together with its principles, textual range and purposes. It scrutinises the methodology behind the study by presenting a broader context including the cognitive theory of religion, formal analysis of myth and cognitive and statistic linguistics. The second part contains the technical analysis of the data mining process and provides a user's manual. The third part furnishes some early findings and observations based on both the qualitative and quantitative evidence gathered in the database: the domination of the pragmatic orientation, the correlation of particular entities and specific genres and the overwhelmingly negative attitude of demons towards humans. Finally, the fourth part points out the most important improvements which need to be made to the existing database and outlines some directions for development and possible applications.
\end{abstract}

Keywords: rabbinic literature, Babylonian Talmud, demonology, angelology

Wojciech Kosion a graduate of Psychology and Religious Studies, adjunct researcher at the Centre for Comparative Studies of Civilisations at the Jagiellonian University. He is currently studying Jewish demonology and angelology.

E-MAIL: wojciech.kosior@uj.edu.pl 


\section{Project history}

The point of departure for the Elyonim veTachtonim [EvT] project was the observation of the liminal nature and ambiguous status of the demons in early rabbinic literature [ERL]. They are portrayed as originating from the union of earthly and spiritual beings (Eruvin 18b) and as such possess partly angelic and partly human qualities (Hagigah 16a). Some other sources claim that the process of their creation was interrupted by the coming of the first Sabbath, which left them bodiless and, as such, partially imperceptible (Avot 5:6; Genesis R. 7:5). This, however, did not impart their effective powers in the material world and the demons appear to be responsible for a wide variety of phenomena: from mingling with the divine plan behind the history of the Jewish people (Yoma 20a), spreading disease (Pesahim 111b-112a) to all the little annoyances encountered on a daily basis (Berakhot 6a). Their impishness notwithstanding, demons are capable of benevolence towards those who know how to deal with them properly: they betray an arcane knowledge (Pesahim 110a), warn of various dangers (Hullin 105b-106a) or allow their hostility to be channeled against the enemies of Israel (Megillah 11b). Thus, the present project started as what seemed at the time to be the relatively simple endeavour of reflecting on the cognitive metaphors applied in the descriptions of demons in ERL, or in other words, explaining how the rabbis dealt linguistically with creatures who are essentially liminal.

Early on, however, it turned out that bulk of theoretical ground work needs to be done beforehand, ranging from establishing the methodological principles up till reconstructing the demonology of the ERL, basing this first and foremost on primary sources rather than on secondary literature that tends to rely on the categories and ideas, which in itself need deconstruction. Thus, for the purpose of the present study, a broad understanding of the ERL is adopted, including the pre-Geonic works conceived in the first millennium of Common Era and thus more or less paralleling the scope set by the Sifrut Chazal category of the Bar-Ilan Online Responsa Project ${ }^{1}$. Apparently, this range is slightly beyond what J. Neusner, an authoritative scholar of rabbinic literature considers to be "early" ${ }^{2}$ - yet, it seems reasonable to somewhat stretch the category and thus include some "liminal" rabbinic works such

1 Bar-Ilan Online Responsa Project, [www 01].

2 See for instance: idem, Rabbinic Judaism, Formative Cannon of, I: Defining the Canon, [in:] Encyclopedia of Judaism, J. Neusner, A. J. Avery-Peck, W. S. Green (ed.), vol. 3, pp. 2113-2120. 
as the younger parts of the Midrash Rabbah collection (e.g. Genesis Rabbah) or the highly influential anthologies Midrash Tanhuma and Pirke de-Rabbi Eliezer. In doing so, the adjective "early" is used to differentiate these texts from the prototypical "late" works of the medieval rabbinic thought such as Zohar, Geonic literature, halakhic codices and biblical commentaries. At first glance, this scope may appear extremely vast, but it has to be kept in mind that even within such a range, demonology occupies a relatively small terrain. Still, however, due to the intended depth of the study, it was necessary to narrow down the extent of investigations and to begin with just one corpus. The Babylonian Talmud [BT] was selected as the most appropriate point of departure for two main reasons. Firstly, this is by far the most often referenced work of the ERL and, as such, has had a crucial impact on other rabbinic texts from this period and beyond. In other words, it can be expected to contain certain patterns of demonological narratives utilised in other, later works. Secondly, although the text in its standard English editions is almost ten thousand pages long and spans the religious and cultural traditions from at least several centuries of the late antiquity, it is still a considerable bargain between its size and representativeness. Thus, despite its sheer volume, the text can be considered a relatively coherent work. Not without significance was also the fact that several English translations of the BT are available on-line as public domain: Rodkinson Talmud, Soncino Babylonian Talmud and the recently published parts of the William Davidson Talmud. Although EvT utilises only the Soncino edition, the users are encouraged to compare different versions on their own.

During the study, it became somewhat natural that this reconstruction took the form of a detailed database, which in itself appears to have numerous potential applications. The idea to construct such an inventory is neither original nor new and the present project has been inspired by other endeavours of this kind. First and foremost, these include general purpose inventories like Aarne-Thompson-Uther Classification of Folk Tales ${ }^{3}$ as well as works dedicated solely to Jewish literature like the now classical Sepher haAggadah $h^{4}$ or its relatively recent, but dynamically developing on-line counterpart which has a rich and carefully edited collection of material in the

3 Multilingual Folk Tale Database. Aarne-Thompson-Uther Classification of Folk Tales, [www 06].

4 H. N. Bialik, Y. H. Rawnitzki, W. G. Braude, The Book of Legends = Sefer ha-Aggadah: Legends from the Talmud and Midrash. 
category of Angels, demons and other creatures ${ }^{5}$. In turn, the consideration that the accounts' literary genres had a significant influence on the interpretation of the contents was informed by the achievements of the Database for the Analysis of Anonymous and Pseudepigraphic Jewish Texts of Antiquity ${ }^{6}$. Last but not least, in terms of the classification of particular supernatural creatures and the organisation of the presentation there was much to learn from numerous dictionaries and encyclopaedias such as the authoritative Dictionary of Deities and Demons in the Bible ${ }^{7}$, the less scientifically rigorous but still informative A Dictionary of Angels including the Fallen Angels ${ }^{8}$ or the very pragmatic and user-friendly Theoi Project ${ }^{9}$. Particular aspects and solutions featured by these and numerous other resources ${ }^{10}$, both in paper and electronic form were incorporated in the present endeavour, aimed at comprehensiveness and a solid grounding in the source texts on the one hand and maintaining the precise form allowing a subsequent quantitative analysis on the other.

Given the precedence outlined above, a few defining features of the EvT inventory need highlighting. First and foremost, the mission of the project is to use an open-access formula both for the creator and the end-users so for this reason appropriate tools - i.e. those freely available on-line - have been selected. The web site runs on the blogspot.com service which offers vast customisation options and convenient integration with other Google tools including Analytics and Scholar. In turn, the database itself is construed in a popular spreadsheet format which can be opened using free software, both online and offline, such as Microsoft Excel Online, Libre Office, Open

5 Sefer haAgadah. Otzar Agadot Chazal beReshet ספר האגרה. אוצר אגדות חז"ל ברשת] [The Book of Legends. The Online Inventory of the Rabbinic Legends], [www 09].

${ }^{6}$ Database for the Analysis of Anonymous and Pseudepigraphic Jewish Texts of Antiquity, [www o2]. Here I would like to express my gratitude to the staff behind the project for organising an international workshop The Literary Structures of Ancient Jewish Literature (Manchester, July 11-12th 2011) which gave me a unique opportunity to learn the technical details of such an endeavour. Special thanks go to P. Alexander and A. Samely with whom I had an enlightening conversation about the nuances concerning the definition of the supernatural creature.

7 K. van der Toorn, B. Becking, P. W. van der Horst (ed.), Dictionary of Deities and Demons in the Bible.

8 G. Davidson, A Dictionary of Angels including the Fallen Angels.

9 Theoi Greek Mythology, [www 10].

${ }^{10}$ Like for instance U. Ehrlich's Prayer in Rabbinic Literature: A Developing Database, [www 04]. 
Office or Google Sheets. More importantly, the basic functionalities of the inventory such as searching and filtering are easily accessible via the web site. Secondly, the project adheres to the values of the open-source initiative and encourages other scholars to use the inventory for their own study. Thus, while the inventory was conceived with some specific research goals in mind, the prospects are broad and limited only by other scholars' creativity. This is also one of the reasons for creating the database as a spreadsheet - although it might not be the most convenient and user-friendly solution, the format allows for a wide variety of additional operations performed on the data itself like simple statistics and correlations. Last but not least, while at this stage the EvT is a one-man project, it is designed so as to eventually accommodate the cooperation of many users and turn it into a Wikipedia-like experience ${ }^{11}$. Exactly due to this last aspect the EvT should be perceived as a constant work in progress. At a certain point, it was necessary to decide whether to wait and upload the "finished" project or to publish an early version with the intention of adding consistent updates. The latter, more modern option was chosen for numerous reasons, the most important of which was the community's feedback - and in fact, right after revealing the EvT to the public, the project was met with robust responses ${ }^{12}$.

\section{Theoretical principles}

The textual modus of the analysed materials translates directly into the methodological paradigms which govern the present project. First of all, there is cognitive linguistics [CL] as established and described by G. Lakoff and M. Johnson $^{13}$ and further developed in the works of Z. Kövecses ${ }^{14}$. Accordingly, language and thinking are metaphorical to the core and from this perspective, the demons can be seen as a literary and mental phenomenon. Several specific theses advanced by this framework prove particularly well suited to the enterprise, namely the imaginative rationality, the basic categories of the source and target domains and the pivotal role of the anthropomorphism

\footnotetext{
${ }^{11}$ In this regard it is worthwhile to mention the Sefaria Project which relies on the input of particular users who translate and comment on the primary sources. [www 08].

${ }^{12}$ Special thanks for the particularly careful feedback go to (in alphabetical order): A. Anczyk, R. Iwicka, J. Proszyk, Ł. Stypuła, N. Tołsty and M. Wójcik.

${ }^{13}$ G. Lakoff, M. Johnson, Metaphors We Live by.

${ }^{14}$ Z. Kövecses, Metaphor: A Practical Introduction.
} 
in the perception of various non-animate phenomena. The first one serves as an apt alternative towards the classical concept of truth and allows the rabbinic demons to be conceptualised as certain tools of thought without delving into a rebuttal or confirmation of the evil spirits' ontological status. Subsequently, the other two concepts allow the demons to be analysed both as an abstract target domain approached with various groups of other metaphors and as a somewhat "tamed" source domain deployed in order to grasp different and non-obvious phenomena. The latter constitutes a special case of anthropomorphism, the prevalent conceptual metaphor according to the CL.

Lakoff and Johnson's linguistic observations with regard to these three ideas dovetail neatly with the premises and findings of the scholars operating under the umbrella term of the cognitive theory of religion [CTR $]^{15}$. The foundations of this approach have been laid down by inter alia S. Guthrie and P. Boyer who understand religion as a belief in the presence and effectual activity of invisible human-like agents. This conviction, however, is not specific to religion solely and is in fact a special case of a more general and evolutionarily advantageous ${ }^{16}$ cognitive disposition to either see the actual "faces in the clouds" 17 or infer something about them from studying the "traces in the grass" 18 . Accordingly, "we act out against computers and vending machines as though they were conspiring against us"19 on the one hand and tend to perceive highly varied and inherently complex phenomena in a simplified form as caused by the activity of some invisible agents. More importantly, this tendency is clearly manifested in language and, as convincingly shown by numerous empirical studies, one does not have to perceive "computers and vending machines" as animate dialogical partners to speak about them in such a manner. No less important is the fact that

15 Although technically the phrase suggests the existence of one single theory, this is not the case, as the CTR contains several sets of hypotheses concerning the origins and the essence of religion. These, in turn, constitute what might be tentatively described as a family of cognitive theories of religion. Since this is the former expression which has gained precedence over the latter, the single form will be used throughout this paper.

${ }^{16} \mathrm{~J}$. Barrett, Why Would Anyone Believe in God?, pp. 32-34.

${ }^{17}$ S. Guthrie, Faces in the Clouds: a New Theory of Religion.

${ }^{18}$ P. Boyer, Religion Explained: the Human Instincts that Fashion Gods, Spirits and Ancestors, p. 164 .

${ }^{19}$ J. Jong, C. Kavanagh, A. Visala, Born Idolaters: The Limits of the Philosophical Implications of the Cognitive Science of Religion, "Neue Zeitschrift für Systematische Theologie und Religionsphilosophie" 57 (2/2015), p. 247. 
the CTR puts a wide variety of entities such as angels, demons, deities and saints in one category of supernatural agents possessing just a few minimally counterintuitive features. As a result, in its simple elegance and phenomenological epoché of the insignificant details the CTR presents a great alternative and a means of leaving the impasse of sterile theological and philosophical speculations.

Both the CL and the CTR prove very useful in the analysis of demons understood as anthropomorphic or, given the literary nature of the analysed sources, even anthropotropic entities. Also significant are the formal aspects of the materials examined and therefore it is important to note two other paradigms which serve as an auxiliary function in the present study. Thus, the third one is the formal analysis of myth as developed by V. Propp ${ }^{20}$. Although the pattern of the dynamic homeostasis in which the protagonist has to restore peace in the world is hardly to be found in the rabbinic narratives, Propp introduces some very useful categories of actants that help to classify literary figures according to the functions they play in the narrative, irrespective of their secondary qualities. Finally, the fourth methodological paradigm governing the present study is quantitative approach in the humanities, especially statistic and corpus linguistics which allow the distribution of particular words and phrases throughout the corpus to be analysed and these regularities to be recognised as witnessing to the actual popularity of given ideas. As it will be argued in the following parts of the present paper, these paradigms acknowledge both the quantitative and the qualitative aspects of the phenomena in question and prove well suited to the study of literary supernatural beings.

\section{Definition of demon}

The initial purpose of the project was the reconstruction of the rabbinic demonology and for this reason the investigations commenced with an inquiry into the semantic nuances of the term "demon". Almost immediately, a swift review of the literature on the subject allowed at least four tendencies present in the conceptualisation of demon to be discerned. The first tendency is to use the term without explication based only on a popular and superficial meaning of the term usually applied to denote some malevolent counterpart of god.

${ }^{20} \overline{\text { V. Propp, Morphology of the Folk-Tale. }}$. 
The second is the definition which contains other non-obvious terms such as "spirit" or "devil" and, as such, fits the category of the formal logical-didactic fallacy of ignotum per ignotum. The third tendency appears to be a special case of the latter because it is based on a juxtaposition with god and angels. Accordingly, god is a good, omnipotent, independent and universally worshipped being, while the angels are obedient, benevolent servants and the demons are neither. Apart from the obvious ignotum per ignotum (or even per ignotius) fallacy, this distinction is not necessarily reflected in the literature itself: the demons - or the creatures which seem to fit the prototypical understanding of a demon - are no more harmful than the deity is; god can be repelled by appropriate acts and paraphernalia ${ }^{21}$ and the angels are often jealous of humans. In other words, the difference between god and demon is more a question of quantity rather than quality, more of the emic perspective rather than the etic and is the result of the development of both the Jewish and Christian theology aimed at promoting one supreme deity capable of subjugating every other being, both natural and supernatural ${ }^{22}$. The fourth tendency is reflected in the translational choices, as the existing renditions tend to apply the word "demon" in at least two meanings: as an equivalent of either shed ${ }^{23}$ or maziq or as the name of a whole class of beings containing particular sub-classes - e.g. spirits (ruchot) as well as specific figures such as Ashmedai or Lilith. From a logical perspective, such a solution is an example of the logical fallacy of equivocation, unless it is explicitly stated that the name is used as a metonymy "the name of a class for the name of the particular exemplary”. Even then, however, the usage remains unclear and ambivalent.

It seems that these problems associated with the word "demon" partially

${ }^{21}$ W. Kosior, "It Will Not Let the Destroying [One] Enter". The Mezuzah as an Apotropaic Device according to Biblical and Rabbinic Sources, "The Polish Journal of the Arts and Culture", 9/2014, pp. 127-144.

${ }^{22}$ Such tendency is present in inter alia two popular encyclopaedias of the Jewish Studies: G. Scholem, Demons, Demonology, in: Encyclopedia fudaica, F. Skolnik, E. Berenbaum (ed.), vol. 5, p. 572-578; Demonology, [in:] Jewish Encyclopedia, I. Singer et al. (ed.), [www 03]. These works are obviously very general in nature, yet the tendency is present in more profiled treatises as well, e.g. G. J. Riley, Demon, [in:] Dictionary of Deities and Demons in the Bible, pp. 235-240.

${ }^{23}$ The paper follows the spelling and transcription rules outlined by the Society of Biblical Literature with some modifications due to the nature of the study. For the detailed rules adhered to in the present paper as well as in the project itself please consult the web site ([www 05]) and the tab "Technicalia". 
stem from the fact that the Greek term is applied in the Semitic entourage. In fact, if to follow the history of the concept on the grounds of Hellenistic culture, it is clear that since its inception the semantic range of the term included a deity, an abstract force, a spirit of a dead ancestor and a ghost inhabiting some place and capable of possessing a $\operatorname{man}^{24}$. Thus, given the semantic range of meaning that "demon" has acquired over time, it was the question of whether it could be deployed in the context of the present project. On the other hand, since the application of the term has some scholarly tradition, it was decided that it would be unwise to relinquish it altogether and thus it was indispensable to postulate a regulating, provisional definition adjusted to the needs of the present project. Thus, the initial proposal was to understand "demon" as a literary anthropomorphic figure that does not belong to other categories such as animals, humans, angels or gods and is portrayed as partially or occasionally invisible and immaterial contrary to the tangible results of its actions. By "literary" it was stressed that the research concerns the textual reality while "anthropomorphic" referred to the ways this figure was construed and portrayed on the basic linguistic and narratological level, especially with regard to its psychical qualities and traits ${ }^{25}$.

\section{Entities and classes}

The next step was to take this definition of demon and to approach the existing treatises on the subject and reconstruct a list of all the demonic appearances in the BT. This stage of the investigations resulted in a line-up consisting of approximately 70 records which differed with regard to their formal qualities: some appeared to be simple assertions of one sentence while others constituted more elaborate accounts. The same could be said about their

${ }^{24}$ A. Klostergaard Petersen, The Notion of Demon. Open Questions to a Diffuse Concept, [in:] Die Dämonen Demons. Die Dämonologie der israelitisch-juedischen und fruehchristlichen Literatur im Kontext ihrer Umwelt/ The Demonology of Israelite-Jewish and Early Christian Literature in Context of their Environment, A. Lange, H. Lichtenberger (ed.), pp. 25-27. L. R. Overstreet, The term "demon" in Greek literature, [in:] Evangelical Theological Society papers, ETS-0708, 1999, [www 07].

${ }^{25}$ Contra: those scholars who insist on differentiating between literary anthropomorphs and demons. J. M. Blair, De-demonising the Old Testament: an Investigation of Azazel, Lilith, Deber, Qeteb and Reshef in the Hebrew Bible. Although the dissertation concerns the Hebrew Bible, the conclusions and the methodological stance can be very well transposed to other corpuses of literature. 
contents which varied significantly and ranged from rabbinic anecdotes and sayings through the retellings of biblical stories to dry catalogues and listings. Although there were some clear and unambiguous passages, more often than not they were composed of various types of texts and the same account could simultaneously feature a story, a saying and a listing (e.g. Pesahim 111b113a). At this stage, it was assumed that the inventory was far from comprehensive and, as such, needed a dedicated search in order to supplement all the accounts which had previously been omitted. The search list was constructed based on the above mentioned roster and contained the following entities: (in alphabetical order): "angel of death", "demon", "devil”, "ghost", "prince", "Satan", "spirit". In addition to this, the list was supplemented with the following personal names: "Ashmedai", "Azazel", "Belial", "Igrath", "Lilith" and "Samael". Afterwards, each word was searched in a manner that included all morphological variants, especially the plural forms. As a result, it was possible to recover previously unmentioned accounts and include them in the database which has thus grown to approximately 180 items with almost $85 \%$ being relatively short snippets of text.

Here, a methodological commentary is in place. The inquiry was performed by means of an electronic search module applied to the Soncino edition of the BT. Certainly, the analysis of the English translation rather than the Hebrew and Aramaic original is methodologically inferior since it relies on already interpreted material. This choice, however, was dictated by pragmatic reasons: to analyse the Semitic original would mean to struggle with all the words which are spelled identically or similarly to the given term. For instance, searching the consonantal form of the word shed in all its antefixal and suffixal variants returns over 2000 records due to the fact that it can denote a breast (Heb. shad), be a part of the name Shadday or an element of the derivates of the roots shadad (destroy) or shadah (nourish). Only $3 \%$ of its occurrence has a demonic significance. In a similar manner, another popular representative of the rabbinic demons, maziq, yields almost 180 records including cases in which it denotes an insect or a propagator of damage in the juridical context with the demonic meaning constituting only a small fraction. Analogically, the search for the third popular term, ruach returns almost 1000 entries including numerous cases in which it denotes a wind with only approximately $4 \%$ denoting a "spirit" understood as an independent and anthropomorphic being. To summarise, performing a search using the original languages would mean a serious extension of the study time that 
would not necessarily mean more exact results. Still, in order to counteract this limitation and to minimise the translation bias, all the accounts collected in the inquiry have been carefully checked against their originals so as to make sure that various wordings are acknowledged. Thus, for instance, the English translation of Soncino did not distinguish between the words shed and maziq and rendered them both as "demon". In fact, in some cases the translators decided on this option with words and phrases which are not usually translated so, for instance, malakhey chabalah is once rendered as "demons" in Berakhot 51a. In other words, although the search commenced with the English version, it then came up with a precise distinction between particular words applied in each context and this was reflected in the inventory itself.

Even a quick glance at the list of demons proves that the roster consisted of highly diverse beings in which the ruach of epilepsy could neighbour Lilit on the one hand and a shed of the privy on the other. It also turned out that the term "demon" was not the most appropriate word to denote the general category of beings. Let us consider Satan and the angel of death: the former is usually listed among the demons in the secondary literature but, upon a closer scrutiny of the sources, it appears to be one of the obedient divine emissaries, sometimes put in the role of the angel of death or the evil yetzer $^{26}$ and, as such, fits the role defined by the narrative in Job $1-2$ and further post-biblical reiterations. Similar is the case with the angel of death: although usually listed among demons due to his unpredictability and apparent malevolence, he seems to remain an attentive divine servant. These two liminal creatures clearly show the blurred lines between rabbinic angelology and demonology. The matter is additionally complicated by the fact that, according to some later classifications, angelology is a special case of demonology or vice vers $a^{27}$. Thus and for the sake of clarity, even at the cost of arbitrarity, at this stage it was decided that the general category which

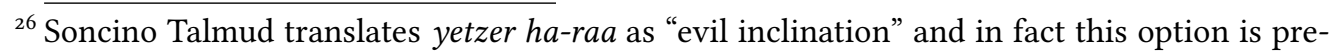
valent in other translations and scholarship as well. Although this rendering suggests that some human psychological quality is intended, its presentation in the BT relies heavily on anthropomorphic metaphors, which allows yetzer to be classified as an entity. See: I. RosenZvi, Demonic Desires. Yetzer Hara and the Problem of Evil in Late Antiquity, especially pp. 65-101.

${ }^{27}$ This is particularly apparent in the theological paradigms that are based on the Enochian myth of the origins of evil. In this regard see: A. T. Wright, The Origin of Evil Spirits: The Reception of Genesis 6:1-4 in Early Jewish Literature. 
has initially been understood as "demon" needs reconceptualisation: in its place, a category called "entity" was introduced to denote a literary anthropomorphic figure which does not belong to other categories such as animal, human or god and which is portrayed as partially invisible and immaterial, yet still capable of influencing the material reality ${ }^{28}$. The "demons" in turn became one of the classes of entities along with angels and ghosts.

The definitions of classes are still provisional and rely on the lists of the representatives of the given class (i.e. its extension) rather than on the exact sine qua non conditions of determining whether a given object belongs to the category (i.e. its intension ${ }^{29}$. In general, demons are entities who tend to be malevolent towards humans, inhabit their close vicinities and act independently. Meanwhile, angels follow divine orders, live in the heavens and remain rather helpful towards humans. Finally, ghosts are deceased humans who appear as if equipped with some additional powers ${ }^{30}$. Obviously, at this stage the division should be understood in terms of family resemblance and phase logics, lacking sharp borders and clear criteria - future investigations will allow for a more precise differentiation between these classes.

\section{Genres, units and pieces}

At this stage, the database contained approximately 180 records of varying length, form and content. The purpose of the next step was to formally unify all the records and to transform them into the basic text-blocks which would later on become the primary units of the study. Throughout this project the word "unit" is understood as a technical term denoting an isolated part of text which is coherent with regard to its formal qualities and at the same time remaining as large as possible to accommodate this coherence ${ }^{31}$. The basis for the separation of each such unit is the genre, hereby understood as

${ }^{28}$ This is in line with the functional conceptualisation of supernatural agents on the grounds of CTR and CL. See: J. Jong et al., op. cit., p. 250.

${ }^{29}$ For the exact list consult the web site ([www 05]) and the tab "Entities".

$3^{30}$ The list should not be perceived as final because it leaves much space for the introduction of other classes. Right now it is possible to hypothesise about "monsters" (entities connected to the cosmogonic accounts, especially as the divine opponents in chaoskampf, like Behemoth or Leviathan) and "gods" (understood mainly as the foreign deities present in the rabbinic discourses).

${ }^{31}$ This latter restriction concerning its size was introduced so as to avoid excessive fragmentation of the source material. 
a formal-thematic type of text. For the purpose of this study the following genres were defined:

- biblical anecdote - a narrative which retells a biblical account with some additional details, most often with the intrusion of some entity into the story, e.g. the reiteration of Job 1-2 with a detailed psychological portrait of Satan (Bava Bathra 15b-16a) or the discussion between Abraham and Satan in the retelling of the aqedah account (Sanhedrin $89 b)$;

- rabbinic anecdote - a narrative which concerns the personal rabbinic encounters with certain entities, e.g. Pelimo struggling with Satan's tricks in Kiddushin $81 \mathrm{a}-\mathrm{b}$ or king Solomon abusing the supernatural skills of Ashmedai in Gittin 68a-b;

- cultic protocol - concerning the ritual issues that involve the entities and most often deal with necromancy (e.g. Chagigah 3 b) and idolatry (e.g. Sanhedrin 61a); it also contains a separate group of references to Azazel who appears almost exclusively in the cultic context (e.g. Yoma 37a);

- pragmatic advice - covering all the down-to-earth details concerning the relationships between humans and entities and boils down to the specific dos and don'ts such as do not wander alone and devoid of any source of light at night (Berakhot $43 \mathrm{~b}$ ) or do not sleep alone in an empty house (Shabbat 151b);

- proverb - applying the name of a particular entity in what appears to be a kind of a proverb, folk wisdom, euphemism or any other conventional manner of speech, e.g. "do not open your mouth for Satan" (Berakhot 6ob), "Satan dances between his horns" (Pesahim 112b) or a "daughter of Belial" (Berakhot 31b); this may also denote a simile - the likening of a certain group of humans to particular entities (Qiddushin 72a);

- statement - presents some traits of a given entity (e.g. the angel of death can perform several tasks on one flight according to Berakhot $4 \mathrm{~b}$ while yetzer ha-raa features a very dynamic growth in Berakhot 61a) or the role of entities in the cosmic order (e.g. the universal hierarchy of humans, angels, demons and animals in Chagigah 16a or their function as defined during the anthropogenesis in Berakhot 6ob); although the examples can be quite complex, involve a detailed visual 
description or a flamboyant simile, they take a form of simple statements or assertions ${ }^{32}$.

What defines a particular unit is therefore its genre and although one unit cannot be classified as more than one genre, the units can constitute more elaborate and composite pieces. Again, the term "piece" is used hereby as a technical designation of a given fragment composed of various units. An apt example of a piece comes in one often cited mention contained in Berakhot 6a:

It has been taught: Abba Benjamin says, If the eye had the power to see them, no creature could endure the demons. Abaye says: They are more numerous than we are and they surround us like the ridge round a field. R. Huna says: Every one among us has a thousand on his left hand and ten thousand on his right hand. Raba says: The crushing in the Kallah lectures comes from them. Fatigue in the knees comes from them. The wearing out of the clothes of the scholars is due to their rubbing against them. The bruising of the feet comes from them.

If one wants to discover them, let him take sifted ashes and sprinkle around his bed, and in the morning he will see something like the footprints of a cock. If one wishes to see them, let him take the after-birth of a black she-cat, the offspring of a black she-cat, the first-born of a first-born, let him roast it in fire and grind it to powder, and then let him put some into his eye, and he will see them. Let him also pour it into an iron tube and seal it with an iron signet that they should not steal it from him. Let him also close his mouth, lest he come to harm.

R. Bibi b. Abaye did so, saw them and came to harm. The scholars, however, prayed for him and he recovered.

This piece can be dissected into three units: a statement containing a series of assertions describing particular features of demons (starting with "It has

${ }^{32}$ For more examples consult the "Database" tab itself ([www 05]). Obviously and as is common on the grounds of the broadly understood humanities, the classification of particular passage to a given genre is at least to some extent arbitrary, even though the genres are rather broadly defined and the construct of "pieces" allows the acknowledgement of various genres. Yet, in order to reduce the bias and secure a certain level of consistency, a classification heuristic has been resorted to throughout the project. See the website ([www 05]) and the tab "Genres". 
been taught..."), pragmatic advice furnishing some means of recognising the presence of demonic activity ("If one wants to discover them...") and a rabbinic anecdote ("R. Bibi b. Abaye did so..."). Another example comes from Pesahim 112b-113a:

'And do not go out alone at night', for it was taught: One should not go out alone at night, i.e., on the nights of neither Wednesday nor Sabbaths, because Igrath the daughter of Mahalath, she and one hundred eighty thousand destroying angels go forth, and each has permission to wreak destruction independently.

Originally they were about a day. On one occasion she met R. Hanina b. Dosa [and] said to him, 'Had they not made an announcement concerning you in Heaven, "Take heed of Hanina and his learning," I would have put you in danger.' 'If I am of account in Heaven,' replied he, 'I order you never to pass through settled regions.' 'I beg you,' she pleaded, 'leave me a little room.' So he left her the nights of Sabbaths and the nights of Wednesdays. On another occasion she met Abaye. Said she to him, 'Had they not made an announcement about you in Heaven, "Take heed of Nahmani and his learning," I would have put you in danger.' 'If I am of account in Heaven,' replied he, 'I order you never to pass through settled regions.' But we see that she does pass through? - I will tell you: Those are the narrow paths [which they frequent], whence their horses bolt and come [into civilized places] bringing them along.

It contains two units: a pragmatic recommendation not to go out on Wednesday and Friday nights due to severe demonic activity ("And do not go out alone at night...") and a rabbinic anecdote about Rabbi Chanina ben Dosa who has subjugated Igrath bat Mahalath and restricted her authority ("Originally they were about a day...”).

\section{Topics and attitude}

After the dissection of particular passages into units according to the criteria outlined above, the database grew to almost 300 genre-classified units and this is the present state of version oo1 of the database. The next step 
was to tag all the records according to their topics - particular themes dealt with in a specific unit. At the present, approximately 75 topics have been defined and organised according to a two-tier system consisting of general and more specific topics ${ }^{33}$. Let us consider the following example coming from Berakhot $43 \mathrm{~b}$ :

R. Zutra b. Tobiah further said in the name of Rab: A torch is as good as two [persons] and moonlight as good as three. The question was asked: Is the torch as good as two counting the carrier, or as good as two besides the carrier? - Come and hear: 'Moonlight is as good as three'. If now you say, 'including the carrier there is no difficulty. But if you say, 'besides the carrier', why do I want four, seeing that a Master has said: To one [person] an evil spirit may show itself and harm him; to two it may show itself, but without harming them; to three it will not even show itself? We must therefore say that a torch is equivalent to two including the carrier; and this may be taken as proved.

The text constitutes a clear example of a pragmatic account as it focuses on the practical means of repelling demons in the night. Therefore, the topictags contain "apotropaic" (first-tier tag) and "light", "night" and "plurality" (second-tier tags). Another illustration is provided by a passage from Pesahim $111 \mathrm{~b}$ which belongs to a longer piece dealing with the demon Keteb:

From, the first of Tammuz until the sixteenth they are certainly to be found; henceforth it is doubtful whether they are about or not, and they are found in the shadow of hazabe which have not grown a cubit, and in the morning and evening shadows when these are less than a cubit [in length], but mainly in the shadow of a privy.

This particular unit is pragmatic and concerns the places ruled by Keteb which are to be avoided. Therefore, the topics are "habitation" (first-tier) and "trees", "shades", "privy" (second-tier). Obviously, each unit can be described by the tags coming from various groups and this is the case with Pesahim 112a which reads:

Our Rabbis taught: A man should not drink water from rivers or pools at night, and if he drinks, his blood is on his own head,

33 See the tab "Topics" ([www 05]). 
because of the danger. What is the danger? The danger of blindness. But if he is thirsty, what is his remedy? If a man is with him he should say to him, 'So-and-so the son of So-and-so, I am thirsty for water.' But if not, let him say to himself, 'O So-and-so, my mother told me, "Beware of shabrire" : Shabrire, berire, rire, ire re, I am thirsty for water in a white glass.'

This pragmatic unit is described by these subsequent topics: "apotropaic" (first-tier) and "pairs", "plurality", "spell" (second-tier) and "habitation" (firsttier) and "food" (second-tier) and "medicine" (first-tier) and "blindness", "hygiene" (second-tier) ${ }^{34}$.

The last and possibly the most arbitrary mode of classification is the attitude or the valence of the emotional relationship between a given entity and human beings. The initial version of the modus differentiated between two sides of this rapport, but since it quickly turned out that the attitude is almost always reciprocal, this bifurcation was forfeited altogether. 4 types of relationship have been defined:

- positive - in most cases, this means that the entities are eager to help humans by various means: by sharing esoteric knowledge (e.g. Berakhot 51a; Shabbat 89a; Pesahim 110a), by performing various tasks (e.g. Gittin 68b) or by simply expressing submission (e.g. Bava Batra 16a);

- negative - the entities afflict humans in a variety of ways ranging from the unspecified (e.g. Berakhot $3 \mathrm{a}-\mathrm{b}$; Eruvin $41 \mathrm{~b}$ ) through evoking medical conditions (e.g. Avodah Zarah 12b; Bekhorot 44b) to various minor nuisances (e.g. Berakhot 6a; Gittin 67b);

- mixed - both positive and negative aspects are acknowledged, for instance, an ambivalent attitude towards the angel of death (Sukkah 53a; Hagigah $4 \mathrm{~b}-5 \mathrm{a}$ ) the spiritual enrichment though harsh lessons administered by Satan (e.g. Qiddushin 81a-b) or the dual working of man's yetzarim (e.g. Berakhot 6ob-61a);

- unspecified - the nature and emotional climate of the relationship cannot be established with certainty and this is the case with both rabbinic anecdotes (e.g. Berakhot 18b) and simple statements (e.g. Eruvin 10ob).

${ }^{34}$ For the sake of convenience and brevity the following manner shall be adhered to: firsttier tag (second-tier tags) and thus, for instance: "apotropaic" ("pairs", "plurality", "spell”), "habitation" ("food") and "medicine" ("blindness", "hygiene"). 
Given the nature of this mode of classification, it should be considered as experimental and provisional. Hopefully, the future scrutiny of the remaining classes will allow for a better theoretical grounding.

\section{Conclusions and considerations}

Although this is a relatively early phase of the project and the inventory is still subject to updates and corrections, the data gathered so far allows some early conclusions to be offered with regard to both the quantitative and qualitative aspects of the BT entities. Firstly, probably the least surprising is the observation that the entities belonging to the class of demons (i.e. the most detailed one in the current version) differ significantly in terms of the sheer quantity of particular entities. For instance, the most popular demon turned out to be shed which surpassed other generic designations and this may, at least to a certain extent, explain why this particular word turned into the name of the whole category. Furthermore, maziq, the other candidate, has just half as many appearances. No less important is the distribution of the units with specific entities throughout the tractates, which proves particularly informative with regard to the figure of Satan belonging to the class of angels ${ }^{35}$. Although at first glance Satan seems to compete with shed in terms of popularity measured by the number of units, the chart clearly shows "peaks" in Bava Batra and Sanhedrin that contain some lengthy retellings of Job 1-2 and Genesis 22 respectively. What is more, the relatively high incidence of ruach and malakh stems from the fact that both of these entities emerge in various "specialisations". Yet, while malakh appears in 3 forms as malakh chabalah (angel of destruction), malakh mavet (angel of death) and malakh sharet (ministering angel), ruach comes in 18 variants in total with the disconnected forms of ruach raah and ruach tumaah as the most prevalent options. A similar regularity has been observed in the case of sar (an angel) which appears alone and in 3 composite forms, namely sar beytzim, sar shamen and sara diyama.

Secondly, the introduction of the attitude as the criteria of classification helped to challenge one oft repeated assumption that the demons of the BT are not "really" demons since they are a part of the religious landscape and, as such, quite often appear to be benevolent towards humans. As the statistics

35 It is important to note that one text unit can be "inhabited" by more than one entity. 
show, approximately $70 \%$ of the units reflect a negative attitude and only in $10 \%$ of cases do the entities appear to be helpful ${ }^{36}$. What is more, even a quick glance at these instances show that they are also atypical in their personage as they consist mainly of rare demons like Yosef, Yonatan or Ben Temalion, who should probably be classified as ghosts rather than demons. When it comes to the contents of these units, it turns out that in $25 \%$ of cases a positive attitude manifests itself in the sharing of knowledge with humans.

Thirdly, the way the inventory is organised allows for some manipulation of the filtering command and thus enables one to discover some other regularities. For instance, 63 units are marked with the habitation topic tag as conveying information about the entities' whereabouts. Only one of these instances speaks of the ruins, while 7 units claim that they are everywhere. Somewhat surprisingly, the most popular place is the privy which is the topic of 10 of the units -8 of which are classified among the pragmatic genre. It may probably be concluded that the rabbis were primarily concerned with the entities inhabiting these locations which were of the utmost practical importance. Another example of some data obtained as a result of the manipulation of tag-filtering comes with the figure of yetzer. It appears in 48 units, which is quite a significant portion of the entities and means that this was a rather important concept for the rabbis. Somewhat counterintuitively, however, only 2 of these units are of the pragmatic genre, which suggests that yetzer was more of a theoretical rather than down-to-earth concept.

Right now it is possible to discern at least several directions of the possible development of the EvT project. These include, first and foremost, supplementing the present inventory with the data concerning angels and ghosts. Each of these classes is quite complex and they contain numerous other names like saraf, kherub and kokhav (angels) or met, nefesh and neshamah (ghosts). A similar procedure will be followed, starting with the reconstruction of the idea based on various existing treatises and then by moving to an analysis of the sources themselves. This is particularly important with regard to the angels and a cautious hypothesis may be advanced that the angels as a group may appear no less hostile towards the humans than the demons. It is also expected that some interesting connections between the groups of demons and ghosts may be revealed. Given the euhemeristic theories of religion on the one hand and the CTR's insistence on the crucial role of the

${ }^{36}$ This chart is not included in the on-line inventory but it can be obtained manually from the data contained therein. 
dead in the "colonisation" of the supernatural dimensions on the other, the undertaking of this issue seems all the more justified.

Obviously, more topics shall be defined. For instance, it seems that issues which deal with liminal activities such as sex and defecation are of particular significance. With time, the inventory will also include more categories of tags. Currently, there are plans for to add 2 rows which would gather data concerning the biblical and rabbinic personage present in a given unit. Thus, it will be possible to determine these literary figures which have particularly well developed demonic or angelic affiliations. According to the frequently repeated claim present in the literature on the subject, it is king Solomon and Rabbi Abaye who are the chief demonologists of the ERL - nevertheless, it seems that this assumption needs to be substantiated and possibly supplemented by other characters.

After introducing the adjustments listed above, the inventory will provide a solid base for the initial purpose of this project, which is the analysis of the metaphorical complexes deployed in the descriptions of supernatural beings. Therefore, it will be possible to verify the early hypotheses that although these are the anthropomorphic and theriomorphic metaphors which occupy the leading positions, no less important, though by far less visible, are the source domains of the elements of nature, especially that of wind. Also, it seems that more attention should be devoted to the metaphors of the physical contact between the entities and humans. The particular case of the application of anthropomorphic metaphors is medicine. An oft repeated claim is that this sphere of culture was particularly prone to explanations that involved the presence and activity of various supernatural agents. It is therefore expected that the diseases mentioned in the ERL should be construed in a manner similar to the entities.

Since the initial purpose was to cover the demonology of the ERL, one of the long-term goals is to broaden the scope of comparison and to include other literary corpuses - first and foremost, the Midrash Rabbah collection. More importantly, however, the method is applicable to other works outside of the range of ERL as well, which means that other contextual works can be taken into consideration. At the time being it seems most justified to start with the incorporation of the Hebrew Bible, as it is an important point of reference ${ }^{37}$.

${ }^{37}$ All the more so, since the initial steps have already been taken. See: W. Kosior, The Angel in the Hebrew Bible from the Statistic and Hermeneutic Perspectives. Some Remarks on the 
Finally, the present study is being conducted based on selected BT editions: one in English and one in Aramaic and Hebrew. This is definitely a weak point of the present project: although one can safely assume that the angelology and demonology of the BT were not a particularly interesting target for censorship, it cannot be excluded that it was subject to manuscript and printing variations. Still, in order to launch the project, it was necessary to narrow down the tasks and select only the most important - there were simply other priorities at this stage and the verification of the data on the various editions and manuscripts had to be postponed to a future date, possibly when more people become involved in the construction of the database.

Interpolation Theory, "The Polish Journal of Biblical Research" 12 (1/2013), p. 55-70. 


\section{Bibliography}

\section{Primary literature:}

1. The Soncino Babylonian Talmud, I. Epstein et al (ed.), Soncino Press, London [1947], [www 11], (access: 11.02.2017).

2. Wikitext Talmud Bavli ויקיטקסט תלמוד בבלי (Wikisource Babylonian Talmud], [www 12], (access: 11.02.2017).

\section{Secondary literature:}

3. Bar-Ilan Online Responsa Project, [www 01] (access: 05.03.2017).

4. Barrett J., Why Would Anyone Believe in God?, Altamira Press, Walnut Creek 2004.

5. Bialik H. N., Rawnitzki Y. H., Braude W. G., The Book of Legends = Sefer ha-Aggadah: Legends from the Talmud and Midrash, Schocken Books, New York 1992.

6. Blair J. M., De-demonising the Old Testament: an Investigation of Azazel, Lilith, Deber, Qeteb and Reshef in the Hebrew Bible, Mohr Siebeck, Tübingen 2009.

7. Boyer P., Religion Explained: the Human Instincts that Fashion Gods, Spirits and Ancestors, Vintage, London 2002.

8. Database for the Analysis of Anonymous and Pseudepigraphic Jewish Texts of Antiquity, [www 02] (access: 11.02.2017).

9. Davidson G., A Dictionary of Angels including the Fallen Angels, Free Press, New York 1967.

10. Ehrlich U., Prayer in Rabbinic Literature: A Developing Database, [www 04] (access: 6.03.2017).

11. Elyonim veTachtonim. Electronic Inventory of Angels, Demons and Ghosts in the Early Rabbinic Literature, [www 05] (access: 4.04.2017).

12. Guthrie S., Faces in the Clouds: a New Theory of Religion, Oxford University Press, Oxford 1995.

13. Jewish Encyclopedia, I. Singer et al. (ed.), [www 03].

14. Jong J., Kavanagh C., Visala A., Born Idolaters: The Limits of the Philosophical Implications of the Cognitive Science of Religion, "Neue Zeitschrift für Systematische Theologie und Religionsphilosophie" vol. 57, No 2/2015, pp. 244-266. 
15. Klostergaard Petersen A., The Notion of Demon. Open Questions to a Diffuse Concept, [in:] Die Dämonen Demons. Die Dämonologie der israelitisch-juedischen und fruehchristlichen Literatur im Kontext ihrer Umwelt/ The Demonology of Israelite-fewish and Early Christian Literature in Context of their Environment, A. Lange, H. Lichtenberger (ed.), Mohr Siebeck, Tübingen 2003, pp. 23-60.

16. Kosion W., The Angel in the Hebrew Bible from the Statistic and Hermeneutic Perspectives. Some Remarks on the Interpolation Theory, "The Polish Journal of Biblical Research”, 12 (1/2013), pp. 55-70.

17. Kosion W., The Underworld or its Ruler? Some Remarks on the Concept of Sheol in the Hebrew Bible, "Polish Journal of Biblical Research", 13 (1-2/2014), pp. 29-41.

18. Kosior W., "It Will Not Let the Destroying [One] Enter". The Mezuzah as an Apotropaic Device according to Biblical and Rabbinic Sources, "The Polish Journal of the Arts and Culture", 9/2014, pp. 127-144.

19. Kövecses Z., Metaphor: A Practical Introduction, Oxford University Press, Oxford 2010.

20. Lakoff G., Johnson M., Metaphors We Live by, University of Chicago Press, Chicago 1980.

21. Morgenthaler R., Statistik des neutestamentlichen Wortschatzes, Gotthelf-Verlag, Zürich 1958.

22. Multilingual Folk Tale Database. Aarne-Thompson-Uther Classification of Folk Tales, [www 06] (access: 11.02.2017).

23. Neusner J., Rabbinic Judaism, Formative Cannon of, I: Defining the Canon, [in:] Encyclopedia of Judaism, J. Neusner, A. J. Avery-Peck, W. S. Green (ed.), Continuum, New York 1994-2004, vol. 3, pp. 21132120.

24. Overstreet L. R., The term "demon" in Greek literature, [in:] Evangelical Theological Society papers, ETS-0708, 1999, [www 07] (access: 12.02.2017).

25. Propp W., Morphology of the Folk-Tale, Austin, Texas 1968.

26. Riley G. J., Demon, [in:] Dictionary of Deities and Demons in the Bible, K. van der Toorn, B. Becking, P. W. van der Horst (ed.), Brill, Leiden 1999, pp. 235-240.

27. Rosen-Zvi I., Demonic Desires. Yetzer Hara and the Problem of Evil in Late Antiquity, University of Pennsylvania Press, Philadelphia, 2011. 
28. Scholem G., Demons, Demonology, [in:] Encyclopedia fudaica, F. Skolnik, E. Berenbaum (ed.), Thomson Gale, Detroit 2006, vol. 5, pp. 572-578.

29. Sefaria Project, [www 08] (access: 05.03.2017).

30. Sefer haAgadah. Otzar Agadot Chazal beReshet ספר האגדה. אוצר אגדות חז"ל ברשת [The Book of Legends. The Online Inventory of the Rabbinic Legends], [www 09] (access: 11.02.2017).

31. Theoi Greek Mythology, [www 10] (access: 11.02.2017).

32. Wright A. T., The Origin of Evil Spirits: The Reception of Genesis 6:1-4 in Early Jewish Literature, Fortress Press, Minneapolis 2015.

\section{Internet resources:}

[www 01] https://www.responsa.co.il/

[www 02] http://literarydatabase.humanities.manchester.ac.uk/Default.aspx

[www 03] http://www.jewishencyclopedia.com/articles/5085-demonology

[www 04] http://w3.bgu.ac.il/hazal/project $/$ Eng $/$ main $. a s p ? a c t i o n=40 \& w h a t=40$

[www 05] http://elyonimvetachtonim.blogspot.com/

[www o6] http://www.mftd.org/index.php?action=atu

[www 07] https://www.academia.edu/8368040/The_Term_Demon_in_Greek_ Literature

[www 08] https://agadastories.org.il/subject/677

[www 09] https://agadastories.org.il/subject/677

[www 10] http://www.theoi.com/

[www 11] https://archive.org/details/TheBabylonianTalmudcomplete SoncinoEnglishTranslation

[www 12] https://he.wikisource.org/wiki/\%D7\%AA\%D7\% ${ }_{9} \mathrm{C} \% \mathrm{D} 7 \% 9 \mathrm{E} \% \mathrm{D}_{7}$

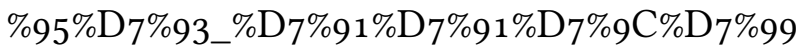

